Japanese Journal of Political Science 3 (2) 195-215 Printed in the United Kingdom (C) Cambridge University Press 2002

\title{
Civil Society in Japan Reconsidered
}

FRANK SCHWARTZ

\section{Abstract}

When defined broadly, we can proceed on the assumption that in all but the most totalitarian of modern contexts, there is some kind of civil society that can be identified and compared cross-nationally. Although Japan may not strike the casual observer as the most fertile ground for such an investigation, setting bounds to the state and freeing space for plurality - the foci of a civil society approach - have long been key issues for that country. Japan may be the strictest of all advanced industrial democracies in regulating the incorporation of nongovernmental organizations, but the 1990 sepresented a watershed in this regard, and the passage of new legislation in 1998 will enable many thousands of organizations to win legal status without subjecting themselves to stifling state regulation.

'Civil society' - the part of the body politic outside the active Government and power system - is virtually unknown in Japan. (Wolferen, 1991)

Japan in the 1990 s is going through a massive political and economic transformation as has never been seen before in the post-World War II era ... [and] the topic of civil society is at the core of the current debate about how to reinvigorate Japan politically and socially. (Imata, 1999: 25)

Academics, politicians, journalists, foundation executives, development assistance officials, regimes and their opponents alike throughout the world - they have all joined the civil society bandwagon. Neoconservatives and East European radicals have raised the banner of civil society to justify the unleashing of market forces. Westerners call for the cultivation of civil society as a prerequisite for Third World democratization. Around the world, state actors themselves have taken to extolling civil society actors as vehicles for the devolution of governmental functions and the reduction of state expenditures.

What of Japan? Can civil society be said to exist at all there; is it just emerging; or, when broadly conceived, is it established and growing ever more vigorous? After defending the applicability of this Western notion to non-Western societies, I will detail the arguments against and for civil society in Japan. Without slighting the 
constraints under which it labors, I conclude that civil society in Japan is stronger than has been presumed, and that current trends are positive.

\section{The Cultural Specificity of Civil Society}

What exactly do we mean by 'civil society'?' Because it touches on so many critical themes, few political concepts have been so protean, and even when they strive for rigor - which they rarely do - different contemporary thinkers stress different aspects, to say nothing of traditions, of the concept, making for ambiguity and outright confusion. Of course, there is no one way in which civil society 'should' be defined; the test of any definition is whether it illuminates a particular problem at hand. For my purposes, I conceive of civil society as that sphere intermediate between family and state in which social actors pursue neither profit within the market nor power within the state. This sphere is occupied by associations including economic actors like employer associations, labor unions, and consumer cooperatives when they are active outside the market (e.g., seeking and implementing public policies) - and by a 'public sphere' of institutions that encourage debate among private persons on matters of common concern, including the exercise of political authority (see Habermas 1989). ${ }^{2}$

Because it developed in distinctively Western milieux, applying the civil society framework across cultures is controversial. Some commentators deny its applicability to non-Western societies altogether. 'The current vogue [is] predicated on a fundamental ethnocentricity', complained Chris Hann (1996: 1). As Hann (1996: 10, 19-20) himself conceded, however, the idea of civil society exerts an obvious attraction to large numbers of people around the world, and it is not the unique product of the West.

1 The general literature on civil society is large and growing rapidly. Nevertheless, a list of the works that this author has found most useful in thinking about the subject (analytically rather than normatively) would have to include (in chronological order): John Keane (1988), 'Introduction' and 'Despotism and Democracy: The Origins and Development of the Distinction Between Civil Society and the State, 1750-1850', in John Keane (ed.), Civil Society and the State: New European Perspectives, London: Verso; Jürgen Habermas (1989), The Structural Transformation of the Public Sphere: An Inquiry into a Category of Bourgeois Society, Cambridge (Mass.): MIT Press; Michael Bratton (1989), 'Beyond the State: Civil Society and Associational Life in Africa', World Politics 41(3); Robert D. Putnam (1993), Making Democracy Work: Civic Traditions in Modern Italy, Princeton: Princeton University Press; Krishan Kumar (1993), 'Civil Society: An Inquiry into the Usefulness of an Historical Term', British Journal of Sociology 44(3); Gordon White (1994), 'Civil Society, Democratization and Development (I): Clearing the Analytical Ground', Democratization 1(3); Víctor M. Pérez-Díaz (1995), 'The Possibility of Civil Society: Traditions, Character and Challenges', in John Hall (ed.), Civil Society: Theory, History, Comparison, Cambridge: Polity Press; John Keane (1998), Civil Society: Old Images, New Visions, Stanford: Stanford University Press; John Ehrenberg (1999), Civil Society: The Critical History of an Idea, New York: New York University Press.

2 Although this definition rests squarely within the contemporary Western mainstream, most Japanese commentators take a less inclusive approach, focusing on civic and advocacy groups, private foundations and philanthropies, and research institutions. For a discussion of definitional debates within the general literature on civil society, see Schwartz (forthcoming). 
In their zeal to defend other cultures, extreme relativists underestimate the extent to which those cultures have borrowed from abroad in the past and overestimate the extent to which they constitute harmonious unities in the present, thus denying their members the fruits of other societies (Keane, 1998: 55-56). Defying abstract considerations of authenticity and universality, ideas and institutions are constantly spreading beyond their place of origin to take root elsewhere, where they may be reconceived in local terms (Iokibe, 1999: 57). Although Middle Eastern societies have been sensitive to Western influence, for example, civil society 'has entered the discourse of the Arab world and become a central concept in current Arab debate over the direction of politics in the region' (Bellin, 1995: 121). In another society wary of Western influence, civil society is 'almost a mantra in Russian politics these days' (The New York Times, 22 June 2000).

The (in)applicability of a concept like civil society cannot be assumed a priori, but must be determined in each individual case empirically (cf. Weber, 1949: 90). The Western origins of the civil society concept are thus irrelevant; applying it elsewhere is less an imposition of alien values than the posing of a set of research questions that may or may not prove illuminating (Norton, 1995: 10). Although it is important to appreciate the historical specificity of civil society, if the contemporary concept arose out of theorizing about the specific historical experience of the modern West, aspects of it can be found in other cultural milieux, whether as the result of indigenous developments or foreign influence. It is not necessary for other societies to Westernize to boast their own civil societies.

When defined broadly, as it is here, we can thus proceed on the assumption that in all but the most totalitarian of modern contexts, there is some kind of civil society that can be identified and compared cross nationally. But why study Japan in particular? Setting bounds to the state and freeing space for plurality - the foci of a civil society approach - are key issues for Japan, and they have been intensely and widely debated by the Japanese themselves, as well as by foreign scholars. In Japan, such debates flared during the Occupation (1945-52), during a period of citizens' movements and popular protests in the 1960 and early 1970s, and during a period of renewed civic engagement that has continued unabated since the mid- to late $1980 \mathrm{os}$ (Bestor, 1999: 2; cf. Deguchi, 1999: 11).

There are many other theoretical justifications for examining civil society in Japan. Western theories require broad, cross-national testing to determine the scope of their applicability; 'with its Western institutions but Eastern cultural background, Japan represents the perfect case of "experimental” variation' (Broadbent, 1998: 6). Recent research has emphasized the complementarity of state and civil society, and students of other regions of the world often pay homage to the instructiveness of the Japanese example in this regard. Theories of social capital, which have provided such a stimulus to the study of civil society, lay at the heart of many analyses of Japanese politics long before that term came into vogue.

The study of Japan's civil society has strong practical as well as theoretical 
justifications. Explorations of the role of civil society in governance are taking place around the world, and building civil society has joined with the encouragement of democracy and the promotion of liberal capitalism as a basic policy objective shared by the United States and Japan in their dealings with the developing world. Only comparative study will permit in-depth analysis of the diverse factors stimulating and constraining the growth of civil society, and Japan's experience offers a useful reference for other countries (Yamamoto, 1999: 8), particularly in East Asia, where Japan's demonstration effect is profound. A better understanding of civil society in Japan can make an important contribution to international dialogue. As the history of US-Japan relations has demonstrated time and again, Americans and Japanese continue to operate on the basis of distinct images of one another that color how they approach issues of common concern. When the subject has arisen, it is often presumed that Japan is a civil society laggard, but such criticism rarely proceeds from a systematic analysis that is put in historical and comparative perspective. Given the growing importance of the civil society framework as a guide for policy around the globe and the importance of Japan as an international actor, it is essential that the debate over civil society in Japan be well informed. ${ }^{3}$

\section{The Case Against Civil Society in Japan}

Japan may not strike the casual observer as the most fertile ground for an investigation of civil society. First, many traditional values (values traditionally promoted by power-holders, at least) are uncongenial to it. Although pluralism and autonomy are essential to civil society, Japan is not a country that celebrates diversity and challenges to authority. Even foreigners who know little else of the country are familiar with the proverb 'the nail that sticks out gets hammered' (deru kugi wa utareru). The word okami, which has long signified the government or authorities, literally means 'those above'. That a modernizing Japan had to coin new words for 'society' and 'public' is telling, and although it came to be translated as 'public', the word oyake originally referred to the house of the emperor and still has strong connotations of 'governmental' (Deguchi, 1999: 15, 19; Yoshida, 1999: 26). ${ }^{4}$ Neatly encapsulated by the old maxims 'sacrifice self in service to the public' (messhi hōkō) and 'respect for authorities, contempt for the people' (kanson minpi), officials called for the subordination of what were regarded as necessarily partial when not

3 Scholars are increasingly applying the civil society framework elsewhere in East Asia. See, for example, Robert Weller's Alternate Civilities: Democracy and Culture in China and Taiwan (Boulder, CO: Westview Press, 2001) and Hagen Koo's State and Society in Contemporary Korea (Ithaca: Cornell University Press, 1993).

4 On the subject of nomenclature, how to translate 'civil society' itself is a subject of dispute among Japanese. Although the term shimin shakai (literally 'citizen society') was generally used in the past, the word shimin (citizen) carries so much ideological baggage that it is becoming common simply to transliterate the English word as shibiru sosaeti. Given its novelty and foreignness, this term is more neutral if less familiar. 
downright evil private considerations to public interests that only the bureaucracy itself could discern and act on.

Even today, when officials retire to assume (what are typically higher-ranking and more lucrative) jobs outside government, they are said to 'descend from heaven' (amakudari). Jealously guarding their authority over the provision of public services, officials have regarded private associations as useful only to the extent that they cooperate with the government or perform functions insufficiently important for the state to shoulder. Independent and voluntary nonprofit activities have long been suspect among the general public as well, with Japanese often viewing nongovernmental organizations (NGOs) as 'exotic, unique, different, strange and bizarre entities' (Yamaoka, 1999: 30).

Second, the market fills much of the space left open by the state. Because Japan's state and business have been joined inextricably since the beginning of the Meiji era in 1868, 'both have shaped and molded public discourse on the public good in such a way that it is extremely difficult to discern the existence of a public sphere standing between the two. The scope for a public sphere in the classic, liberal sense, therefore, has throughout modern Japanese history been extremely limited, in addition to being dominated by marketplace issues' (Hardacre, 1991: 219). In fact, postwar Japanese discussion of civil society has until recently been inseparable from debates about the nature of Japanese capitalism (Barshay, forthcoming). The hegemony of corporate management and the integration of workers as members of corporate communities rather than as citizens of political society as a whole have prevented Japanese labor unions from becoming important actors in civil society (Suzuki, forthcoming). Japan's consumer movement has met with mixed results in its struggle to represent the interests of its constituency and educate individuals about their rights and responsibilities as consumers and citizens (Maclachlan, forthcoming).

Finally, it is important not to reify 'the state' - some agencies, like the Public Prosecutors Office, are actually more accountable in Japan than elsewhere (Johnson, forthcoming) - but, to generalize, the Japanese state has intervened in civil society in an unusually profound way (Garon, 1997). In this respect, modernization brought fewer changes than might have been expected. Because it centralized state power and heightened officials' prestige, the Meiji Restoration of 1868 reduced what vigor private nonprofit activities had enjoyed during the previous feudal Tokugawa period (Deguchi, 2000: 18-19). Fukuzawa Yukichi (1835-1901), the preeminent intellectual of his age, refused to accept any government appointment precisely because he saw a pressing need to set an example of independence in a country whose citizens relied so heavily on the state (Iokibe, 1999: 67-68). Prewar Japan was marked by a 'failure to draw any clear line of demarcation between the public and private domains', asserted Maruyama Masao (1963: 6). The fact that the development of a modern state in Japan was prompted and guided in response to external necessity encouraged the assumption that 'the state is a prior and self-justifying entity, sufficient in itself', and the 
external imposition of democracy after the Pacific War permitted that mentality to survive (Matsumoto, 1978: 38, 36).

New research provides additional empirical support to the thesis that civil society in Japan has been handicapped by an unusually interventionist state. In the aftermath of Aum Shinrikyō's attacks, for example, state monitoring of religion has tightened, undermining its position in Japan's civil society (Hardacre, forthcoming). Although the Internet has the potential to alter the situation, the mass media have frequently worked together with, or on behalf of, Japan's political core to delimit rather than augment the discursive realm (Freeman, forthcoming). The Japanese state has not only adopted an activist stance vis-à-vis civil society as a whole, it targets policies at specific groups and sectors (Pharr, forthcoming). On a micro level, the informal discretion enjoyed by Japanese bureaucrats permits them to advantage some associations at the expense of others (Estévez-Abe, forthcoming). Thus, state influence in Japan has consciously molded civil society to produce a plethora of small, local groups and a dearth of large, professionalized, independent organizations (Pekkanen, forthcoming). As one example of this conscious process of molding, state policies accounted for both the way Japanese international development NGOs long lagged behind their Western counterparts and for the way they have boomed since the mid-1980s (Reimann, forthcoming).

The main vehicle for state intervention in civil society is regulation, not repression. Japanese enjoy a high degree of freedom - in recent years, Freedom House ( $w w w$.freedomhouse.org) has consistently rated their political and civil rights as (a high) 1 and 2 respectively on its seven-point scale - but Japan may be the strictest of all advanced industrial democracies in regulating the incorporation of NGOs. Organizations must obtain the status of 'legal person' (hōjin) to have legal standing. Although it is possible to operate without that status, groups lacking it cannot sign contracts, and that makes it impossible for them to do such things as open a bank account, own property or sign a lease for office space, undertake joint projects with the government, or even lease a photocopy machine (Pekkanen, 2000: 113). The lack of legal standing may also deprive organizations of social recognition they would otherwise win.

Although Article 21 of the Meiji Constitution guaranteed freedom of association, Article 33 of the Civil Code of 1896 required that all legal persons be formed in accordance with its regulations. And while Article 35 of the Code provided for the establishment of for-profit organizations, rather than provide for a corresponding category of nonprofit organizations, Article 34 provided only for the much narrower category of 'public-interest corporations' (kōeki hōjin). Specifically, 'an incorporated association or foundation ${ }^{5}$ relating to worship, religion, charity, science, art or otherwise relating to public interests and not having for its object the acquisition of

5 The difference between incorporated foundations (zaidan hōjin) and incorporated associations (shadan höjin) is more legal than practical. 
gain may be made a juridical person subject to the permission of the competent authorities'.

As Robert Pekkanen (2000: 116-117) forcefully argues, 'This creates a legal blind spot - most groups that are nonprofit but not in the "public interest" had no legal basis whatsoever to form . . . There was simply no legal category for these groups to exist in and, as a result, they were reduced to operating as informal, voluntary groups, or perhaps even becoming [limited liability] corporations. ${ }^{6}$ Occupation pressure and a movement for revision of Japan's civil law in the early postwar period resulted in several reforms. Separate, less-restrictive laws were enacted to regulate such specialized organizations as private school corporations (gakkō hōjin), social welfare corporations (shakai fukushi hōjin), religious corporations (shūkyō hōjin), and medical corporations (iryō hōjin), and governors were empowered to approve the incorporation of organizations that operated within the borders of a single prefecture. Otherwise, that part of the Civil Code regulating public-interest corporations remained unchanged into the $1990 \mathrm{os}$.

The important points here are that a public-interest corporation had to operate for the public good and had to win the permission of the competent state authority to gain legal recognition. First, activity for 'the public interest' was interpreted to mean for the benefit of society in general or of many and unspecified persons. Activity for the benefit of specific groups was ipso facto regarded as for a private interest (Amemiya, 1998: 64), and this legal interpretation actually narrowed over time. National ministries and prefectural governments reached an agreement in 1972 that only nonprofit organizations with clear, unambiguous, and direct public benefits were to be granted the status of public-interest corporation. Those corporations approved before 1972 retained their legal status, but so-called 'intermediate organizations' (chūkan hōjin) like business organizations, sports clubs, and alumni associations, which do not necessarily have public benefit among their primary objectives, no longer qualified for incorporation as public-interest corporations (Amenomori and Yamamoto, 1998: 4). The incorporation of organizations that were set up for neither the public interest nor economic gain required passage of special, separate laws for that purpose. Second, 'the competent authorities' who granted incorporation were normally officials of the ministry with jurisdiction over the field in which an organization was active. But because of a lack of explicit and standardized criteria, bureaucrats decided on a case-by-case basis at their own discretion whether to approve or reject applications for incorporated status, and groups whose activities cut across ministerial jurisdictions were in a special bind.

Unless the government itself took the lead, winning state approval as a publicinterest corporation was a very difficult process. The Civil Code stipulated that successful applicants had to have 'a sound financial basis', and government agencies

6 On the basis of an examination of the framing of Japan's Civil Code, Pekkanen (2000: 117) goes further to argue that 'this disincorporation by categorization was deliberate'. 
generally interpreted that clause to require an endowment of at least $¥ 300$ million (about $\$ 2.4$ million). In addition, they had to have an annual budget of $¥ 30$ million (about $\$ 240,000$ ), an activity plan, and a board consisting of publicly respected individuals to be eligible for incorporation. Even when these demanding conditions were met, it normally took from several months to a year to explain the application to the appropriate ministry before it granted incorporation. Just as firms often hire retired bureaucrats to maintain relations with their government regulators, there was a trend for organizations to employ officials who could expedite the application process thanks to their ministerial connections, but that practice also had the potential to compromise an organization's independence. Once registered as a legal entity, an organization was then obliged to submit a budget and a plan of proposed activities before the start of each fiscal year, and a financial report and description of its activities after the end of the year. These reports were closely scrutinized, and accounting procedures required adherence to rigid guidelines. A ministry could revoke incorporated status if, in its judgment, an organization failed to fulfill its requirements (Yamamoto, 1999: 108; Menju and Aoki, 1995: 150).

Such an exhaustive application process and such intrusive supervision discouraged organizations from registering. In contrast to the 1,140,00o groups to which the Internal Revenue System had granted nonprofit status in the United States, only 26,089 Japanese groups had attained legal status as public-interest legal persons by the mid-199os (Pekkanen, 2000: 113). As a result, unincorporated associations (nin'i dantai) greatly outnumber public-interest corporations. Positively encouraged by the state, community organizations are extremely numerous. Throughout the country, there are an estimated 275,00o local mutual-help organization (jichikai or chōnaikai), 150,000 children's associations (kodomokai), and 130,00o clubs for the elderly (rōjin $k u r a b u$ ), as well as youth clubs (seinendan) and women's organizations (Amenomori and Yamamoto, 1998: 12-13). ${ }^{7}$ A survey (Economic Planning Agency, 1997) conducted at the end of 1996 turned up 85,786 nonprofit 'citizen activity organizations' (shimin katsudō dantai) that undertook social activities on a continual and voluntary basis but lacked corporate status, and this category included many of Japan's most dynamic associations.

Unincorporated organizations labor under financial handicaps, however. Publicinterest corporations are exempt from the corporate income tax and the taxation of interest income, and beyond a certain percentage, their business activities are taxed at a reduced rate. ${ }^{8}$ Unincorporated organizations do not enjoy these abatements. As for

7 Inclusion of these organizations yields extremely high membership rates in Japan. Even in the late 1960s, before associational activity began to decline in the United States, 72 percent of Japanese belonged to some sort of private organization versus only 61 percent of Americans, and almost twice as many Japanese as Americans (59 percent v. 30 percent) belonged to nonpoliticized organizations (Verba, Nie, and Kim, 1978: 100-101). As Sheldon Garon (forthcoming) points out, however, the extent to which these community organizations can be regarded as 'private' is open to debate.

8 Japan and the United States are opposites in this regard. In Japan, public-interest corporations 
contributions, 'the treatment of individual and corporate donations to nonprofit organizations is uneven and seemingly arbitrary' (Yamamoto, 1998: 124). Winning financial privileges is even more difficult than incorporating, and those privileges must be renewed every two years. As of 1996, contributions to a mere 3.4 percent of all public-interest corporations were tax deductible. Donations are eligible for different levels of tax deductibility depending on the status of the recipient organization. In the absence of a unified treatment for contributions, the Ministry of Finance can extend two designations of special tax status at its own discretion: 'special publicinterest-promoting corporation' (tokutei kōeki zōshin hōjin, or tokuzō) and 'designated donation recipient' (shitei kifu). Most of the former are created by government agencies, staffed by seconded officials, and financed with state subsidies. Only recently was an organization free of government control and acting as something other than an auxiliary for the public sector granted the status of special publicinterest promoting corporation (Yamamoto, 1998: 123, 134; 1999: 109). What tax incentives exist encourage corporate philanthropy more than citizen initiatives, and unincorporated organizations are altogether ineligible for tax-exempt contributions.

The severe restrictions on tax-deductible contributions make it difficult for some private organizations to maintain their autonomy vis-à-vis the state. Coming on the heels of strong national regulation (and Japan's unhappy experience with State Shintō) during the prewar and war years, Article 89 of the postwar constitution rendered private organizations ineligible for state funds: 'No public money or other property shall be expended or appropriated for the use, benefit or maintenance of any religious institution or association, or for any charitable, educational or benevolent enterprises not under the control of public authority'. This stipulation was intended to establish a clear legal divide between the public and private sectors, freeing the latter from the former's control and interference. At the same time, however, Article 25 committed the state to promoting social welfare, and Article 89 was eventually reinterpreted to permit government support for private organizations that supplement public services under strict supervision. ${ }^{9}$ Although the state is thus obliged to provide social services, private organizations are expected to supplement public services where necessary, and most social welfare corporations are heavily dependent on public support, which constitutes an average of 80 to 90 percent of their income. As a result, social welfare corporations may be private nonprofit organizations from a legal perspective, but they operate as quasi-governmental

do not gain tax exemption by means of a uniform process, but by virtue of being incorporated by the ministry with jurisdiction over their particular field. In the United States, on the other hand, tax-exempt status is determined solely by the Internal Revenue Service in compliance with laws that are not directly related to the granting of corporate status (Yamaoka, 1999: 24).

9 Although most public-interest corporations have resulted from private initiatives, they became associated with public services, and the word kōeki - public interest - came to have a connotation of government interest. Those bodies that do not substitute for the government have had to fight an uphill battle to prove that they do in fact represent private initiatives (Imata, 2001). 
organizations, subcontractors that are established to perform tasks entrusted to them by the national and local governments (Amenomori and Yamamoto, 1998: 6; Pekkanen, 2000: 119). ${ }^{10}$

Social welfare corporations lie at one end of a spectrum: nearly all government subsidies flow to either health or social service programs, and private revenue in the form of fees, sales, and charges far outweighs government subsidies for every other type of organization (Yamamoto, 1998: 126). ${ }^{11}$ In 1995, public-sector payments accounted for 86.9 percent of the revenue of groups concerned with health, 71.6 percent of those concerned with social services, 37 percent of those concerned with development and housing, 27.2 percent of those concerned with civic issues, 26.5 percent of those concerned with the environment, 19.2 percent of those concerned with international affairs, 13.1 percent of those concerned with education, 6.9 percent of those concerned with culture and recreation, and 0.2 percent of professional associations (Yamauchi et al., 1999: 257). It should be pointed out, however, that a relatively small number of organizations receive a relatively large share of government subsidies, and the presumption is that these organizations enjoy a patron-client relationship with their ministerial sponsors (Yamamoto, 1998: 127). Furthermore, most of the organizations that do not currently receive government subsidies, wish they did. According to a comprehensive survey conducted in 1997 (Wada, 1999: 178), 34.5 percent of citizens’ groups had annual expenditures under $¥ 300,000 \quad(\$ 2,400)$, and 21.2 percent under $¥ 100,000$ ( $\$ 800)$. Only 23 percent of the groups had full-time paid staff and fewer than 7 percent their own office. It is not surprising, then, that over 80 percent of these groups regarded government support as necessary.

\section{The Case For Civil Society in Japan}

All that said, it would be a mistake to overemphasize state primacy. Civil society should not be treated as a dependent variable vis-à-vis the state. Max Weber (1952: 183) concluded his seminal investigation of the influence of the Protestant Ethic on the spirit of capitalism with the following caveat: 'It is, of course, not my aim to substitute for a one-sided materialistic an equally one-sided spiritualistic causal interpretation of culture and of history. Each is equally possible, but each, if it does not serve as the preparation, but as the conclusion of an investigation, accomplishes equally little in the interest of historical truth'. Correspondingly, neither the accountability of Japan's state nor the voice of its civil society can be ignored.

As Sheldon Garon (forthcoming) argues, Japan's state and civil society co-

10 In contrast to this critical assessment, Takashi Inoguchi (2000: 77, 84) maintains that nonprofit organizations created as local government affiliates are established to create and maintain social space for civic engagement on the grass-roots level with resources made available on the nonprofit principle. This constitutes one arm of local governments' empowerment policies that have been underway for the last two decades or so'.

11 Because of 'the unusual private character of health care' found there, Lester Salamon and his colleagues (1999: 20-21; Yamauchi et al., 1999: 249-251) categorize the nonprofit sector of Japan (and the United States and the Netherlands) as 'health-dominant'. 
evolved over the course of the twentieth century: in a pattern that was to be repeated many times (and sometimes still is), bureaucrats have enmeshed societal groups, making it difficult for them to challenge the state, but those very same groups could be quite assertive, forcing the state to incorporate private actors and their disputes into the apparatus of governance. He outlines this interaction in the following way. From the turn of the century, lawyers, doctors, teachers, civil servants, and salaried employees began organizing themselves into professional associations that were willing to work with the state to realize their objectives. As civil society and the state became increasingly intertwined, officials themselves sought to mobilize society through chambers of commerce, agricultural cooperatives, and the like to further state policies. Although the imposition of officially organized associations impeded the development of an autonomous civil society, these associations had a certain capacity to differ with the state.

The 1920 and early 1930 s witnessed the appearance of new sociopolitical forces labor unions, unions of tenant farmers, and the so-called 'new religions', among others - that lay outside state domination. State-run organizations attempted to absorb all autonomous groups from the mid-193os, but they could not turn back the clock and eradicate civil society even during wartime. The Occupation consciously aimed at removing legal restraints on collective action and promoting the independence of civil society. It failed to implant the ideal of voluntary associations completely devoid of state interference and to destroy officially created local associations, but it did free labor unions, new religions, and women to organize and challenge the political establishment.

Civil society has been burgeoning in postwar Japan. Beginning with sectoral organizations rooted in key industries and followed by 'policy-beneficiary' organizations concerned with the distribution of government resources and finally 'valuepromotion' organizations devoted to particular ideas or movements, interest groups proliferated in Japan over the first two decades of the postwar period (Muramatsu, Itō, and Tsujinaka, 1986). Tsujinaka Yutaka (1996: 18) has found strong trends toward even greater participation and pluralization since then, with Japan's level of associational activity steadily catching up with America's (which has changed little). In 1960, Japan's density of nonprofit associations was only one-third that of the United States (11.1 associations per 100,000 people versus 34.6). By 1991, however, Japan had reached a level more than 80 percent of America's (29.2 v. 35.2).

Aggregate pluralization aside, the composition of the interest-group sector has shifted, as the previous dominance of business groups has weakened. A growing divergence of interests has 'hollowed out' established federations of businesses (and labor unions), and increasing moderation among formerly ideological and confrontational groups has enhanced their access to the policy-making process and reduced the leverage of traditional interest groups (Tsujinaka, forthcoming; 1996: 39, 53). Among those traditional groups, even organizations that owe their existence to topdown directives of the state like the agricultural cooperatives have succeeded in 
enhancing their independence over time by taking advantage of the countervailing leverage offered by postwar democracy's competitive elections (Bullock, forthcoming).

The uneven distribution of resources may still favor established interest associations, but Tsujinaka (1996: 57) has found that newer, citizen-initiated movements enjoy a dynamism and mass appeal that the former lack. Because the citizens' or resident movements (shimin or jümin undō) that mobilized large numbers of ordinarily apolitical Japanese from the 1960s through the early 1970 s tended to be locally based and limited to protesting against specific grievances, ameliorative government policies dampened their activity, and many disbanded once they achieved their immediate goals. Civic involvement experienced a resurgence in the mid- to late 1980 , however, and has grown substantially since then. Coinciding with a decline in confidence in government among virtually all the advanced industrial democracies (Pharr and Putnam, 200o), the general public - and some leaders - in Japan have concluded that the state lacks the flexibility and resources to cope with increasingly complex socioeconomic issues, and more and more citizens have responded with their own initiatives.

Thanks in large part to exogenous developments, NGOs and nonprofit organizations (NPOs) have become household words in Japan. ${ }^{12}$ In a watershed event, many Japanese got involved in helping Indochinese refugees in 1979, and NGOs gained visibility in the late 1980s, when many of the dramatic changes sweeping Japan were attributed to the country's internationalization (kokusai-ka). They have benefited from exposure to and cooperation with foreign organizations at home and abroad, and Japan's NGO movement gained new momentum thanks to a series of United Nations conferences held in the 1990s. Although they often regarded NGOs as interlopers in what should remain affairs of state, Japanese officials were faced with the reality of these organizations' playing a substantive role in shaping international treaties and with the international expectation that they, too, should include representatives of NGOs in their delegations and even subsidize their activities. The move away from patron-client relations that began in the government's treatment of internationally oriented organizations is now being extended to more and more domestic groups (Yamamoto, 1999: 99-103; Yamamoto, 1998: 131, 140, 151; Menju and Aoki, 1995: 143-146).

Although there is no end to arguments over whether Japan is 'really' changing, the 1990 s witnessed epoch-making developments. Due to recurrent corruption scandals, the Liberal Democratic Party (LDP) was finally (if temporarily) thrown out

12 In Japanese usage, these terms have narrower meanings than in English. Because they were the first organizations to adopt the label, Japanese tend to use NGO for groups that are active in international relations, especially civic groups involved in international development cooperation. They are thus distinguished from NPOs, by which Japanese mean less the totality of nonprofit organizations than domestically active civic groups, especially voluntary groups not incorporated as public-interest corporations (Wada, 1999: 173, 181). 
after 38 years in power in 1993, and, as political turmoil continued, voter identification with parties plunged. Distrust of politicians was nothing new, however. What was new was plummeting confidence in the central bureaucracy. An officialdom that had long been credited with Japan's rapid climb to prosperity and prestige demonstrated inflexibility, incompetence, and occasionally downright malfeasance in a long string of failures that included the distribution of HIV-tainted blood, the bursting of a speculative bubble, the bailing out of housing loan companies ( jūsen), systematic bill-padding and toleration of lavish entertaining at the taxpayers' expense, and inadequate management of several nuclear accidents. By the start of 2001, the confidence of Japanese in their Diet and national bureaucracy had fallen to 9 and 8 percent respectively. The comparable figures for the United States were 63 and 51 percent (The Daily Japan Digest, 19 January 2001).

The most dramatic demonstration of the limitations of the state and the growing prominence of civil society came in 1995 . On 17 January of that year, the Great Hanshin-Awaji Earthquake struck the Kōbe-Ōsaka area, killing 6,430 people and obliging another 310,000 to evacuate their homes. The disparity between public and private responses to the disaster could not have been starker. Despite the devastation, jurisdictional disputes and red tape paralyzed the government's relief efforts; dismayed by the disorganization of the government's efforts, about 1.3 million volunteers converged on the affected area and spontaneously organized themselves. Apart from emergency relief on the heels of the earthquake, official financial assistance did not go beyond low-interest loans and the provision of public housing; private donations amounted to $¥ 160$ billion ( $\$ 1.28$ billion). The disparity extended to incorporated versus unincorporated NGOs. Because the former require authorization for their activities from bureaucratic agencies that are themselves highly compartmentalized and turf-conscious, they could not escape the straitjacket of sectionalism. A group that sought permission from the Ministry of Foreign Affairs to establish an organization 'to help the children of the world' was warned that activities in Kōbe would be inconsistent with its objective because 'children of the world' refers to children overseas (Deguchi, 1999: 12). Although that may have been an extreme case, few of the groups that assisted with the relief effort enjoyed any legal status (Pekkanen, 2000: 114; Yamamoto, 1999: 109).

'In the face of that horrific disaster and that marvelous outpouring of voluntary effort, people began to imagine the potential of civil society in Japan' (Bestor, 1999: 7). Celebrating an 'NPO boom' and a 'volunteer [borantia] revolution', the mass media repeatedly, graphically, and invidiously compared the public and private responses to the catastrophe. ${ }^{13}$ The media had started paying attention to the

13 Even before the quake, the mass media had tarnished the image of incorporated public-interest corporations. They were portrayed as 'one of the last sacred places where bureaucrats can do anything they want without being exposed to public scrutiny'. Stories about kōeki hōjin typically focused on mismanagement, the improper use of funds, a lack of transparency, or some kind of collusion with government (Imata, 2001). 
importance of civil society prior to the earthquake, but Kōbe added an extra fillip to such coverage. The combined number of articles on NGOs and NPOs in the Asahi Shinbun, Yomiuru Shinbun, and Mainichi Shinbun, three major dailies, soared from 178 in 1990 to 1,455 in 1994. After the earthquake, the number jumped to 2,151 in 1995 and continued to rise, reaching 2,868 in 1997 (Yamamoto, 1999: 101-102). This media attention raised people's consciousness about the contributions unincorporated groups could make, thereby replacing the anti-government, anti-business reputation they had inherited from the citizens' movements of the 1960 s and 1970 s with a much more favorable image (Deguchi, 1999: 15).

Citizen groups and NPOs had established a coalition in 1994 to support new legislation that would enable private groups to incorporate outside the jurisdiction or influence of government agencies. Because the obvious lesson of Kōbe was that the existing legal framework hampered the growth of a vibrant civil society in Japan, pressure immediately mounted for such a change, and only ten days after the earthquake, the government itself spoke publicly of the need to redress the situation. With as many as 18 government ministries and agencies rushing to respond, officials formed a liaison committee for volunteer groups. Although bureaucrats normally draft legislation in Japan, all the country's political parties submitted or amended legislation regarding private nonprofit groups between 1995 and 1998, and not only did citizen groups participate actively in the debate, but their lobbying substantively affected the contents of the bills under consideration (Pekkanen, 2000: 112). This level of dialogue among government officials, political parties, and citizens' groups over pending legislation was unprecedented.

After long and heated deliberations, the so-called NPO Law (Tokutei hieiri katsudō sokushin hō, or Law to Promote Specified Nonprofit Activities - some conservative politicians objected to the progressive connotations of its original name, the Law to Promote Citizen Activities) finally passed with the unanimous consent of the Diet on 25 March 1998 and went into effect in December of that year. Under the new law, incorporation is not much more than a formality for nonprofit groups that conduct most of their activities in one of 12 specified fields. ${ }^{14}$ Prefectural authorities (or, in the case of organizations operating in more than one prefecture, the Economic Planning Agency, which is now part of the Cabinet Office) have little choice but to grant corporate status to these organizations when they are established in conformance with the provisions of the law - it is no longer left to the discretion of

14 The law explicitly listed activities for: the promotion of health, medical, and welfare services; the promotion of social education; the promotion of community-building; the promotion of culture, arts, or sports; the preservation of the natural environment; disaster relief; regional security; the protection of human rights or promotion of peace; international cooperation; building a participatory society that treats both sexes equally; the promotion of sound rearing of children; and communication, advice, or assistance for organizations that perform any of these activities. 
bureaucrats in the national ministries - and they must normally decide on applications within four months, clearly explaining any decision to withhold certification.

Government officials fought tenaciously to retain their right to supervise private organizations, and some politicians, particularly within the ruling LDP, were skeptical of civil society's playing a greater role (Yamamoto, 1999: 115). It did not help that 1995 was also the year Tokyo's subways were gassed by the cult Aum Shinrikyō, which was itself an incorporated nonprofit organization. Thus, the NPO Law failed to satisfy reformers' expectations, to say nothing of their hopes. One scholar (Deguchi, 2000: 20) went so far as to charge that 'the government's NPO measures still fall short of those provided by the Tokugawa government in the Edo period [1600-1868]'. Rather than clarifying the status of citizens' groups in general by amending the Civil Code to provide for organizations that are neither profit-making nor public-interest bodies, the law only facilitated the operation of a fraction of those groups by slapping a complicated patchwork of provisions onto the inadequate, preexisting legal framework (Deguchi, 1999: 16). Fearing tax evasion and a diminution of their power to allocate resources, bureaucrats adamantly opposed the granting of tax deductibility for contributions to NPOs (Yamamoto, 1999: 110). The law offered no tax privileges, but it did provide for a review of the issue within three years of the time it went into effect, and the government finally began to permit the deductibility of contributions in $2001^{15}$

Pekkanen (2000) is hopeful that the NPO Law represents a milestone. With its citizen-group lobbying, Diet member bills, and devolution of authority to prefectural officials, passage of the law may erode central bureaucratic decision-making. It will enable thousands upon thousands of organizations to win legal status without subjecting themselves to stifling state regulation. By the end of 2001, 6,547 organizations had applied, and 5,625 of those organizations had already been certified (see

15 In its December 2000 'Outline of Fiscal Year 2001 Tax Reform', the Ministry of Finance proposed:

Certain nonprofit corporations [i.e., incorporated NPOs] that are given legal person [hōjin] status under the Law to Promote Specified Nonprofit Activities and that are certified by the commissioner of the National Tax Administration as having satisfied certain requirements shall be subject to the following special tax treatment:

- contributions made by individuals shall be deductible from income;

- apart from the amount allowable for general contributions, contributions made by corporations shall be included in expenses along with contributions made to special public-interestpromoting corporations $[$ tokuzō] up to the limit of said amount allowable, the two combined;

- when an individual has contributed inheritance property, etc., it shall not be included in the calculation of value for the inheritance tax.

The cabinet approved that proposal on 16 January 2001, and the measure went into effect on 1 October (see the Ministry of Finance websites www.mof.go.jp/genan13/zeioo2/1.htm and www.mof.go.jp/singikai/zeicho/toshin/zeichog3.htm, and a website of the NPO C's at www.npoweb.gr.jp/topico2.html). Although this reform represents a big step, certification by the National Tax Administration will not be easy to win, so most NPOs will not be in a position to benefit from these exemptions (Kuroda Kaori, personal communication). 


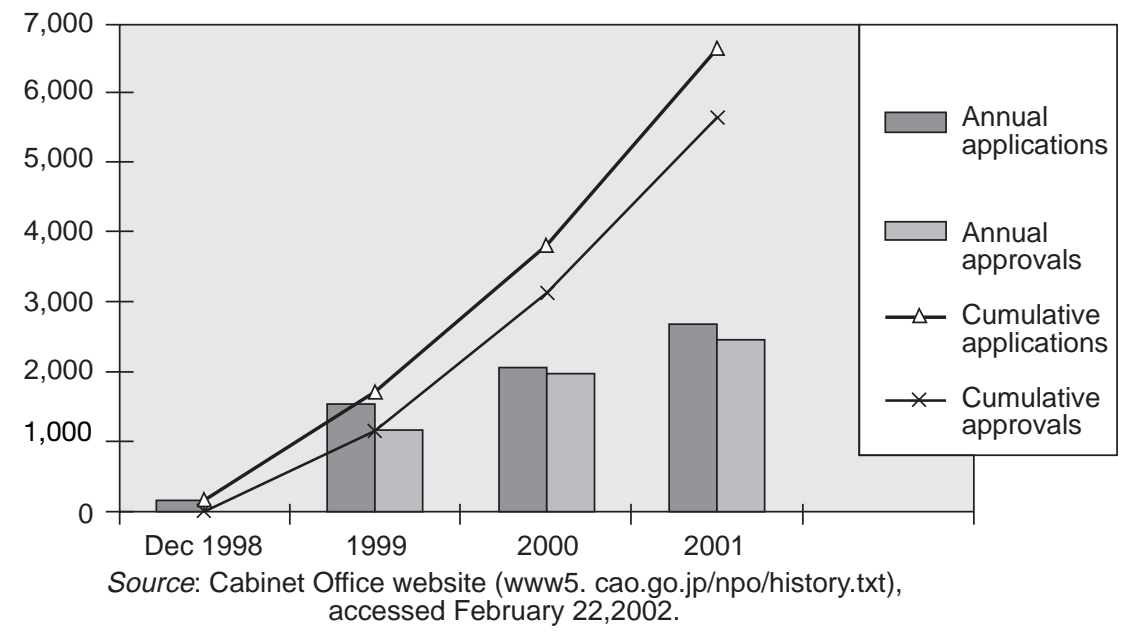

Figure 1. The incorporation of nongovernmental organizations under the NPO Law Source: Cabinet Office website (www5.cao.go.jp/j-j/npo/history.txt), accessed February 22, 2002

Figure 1). 'Perhaps most importantly', Pekkanen (2000: 112) concludes, 'the law legitimates a new kind of social group and, by implication, a shift in the state-society power balance'. The NPO Law undermines the idea that the state has a monopoly over matters bearing on the public interest even as it confers on nonprofit activities the official imprimatur that has so long been necessary and lacking (Deguchi, 2000: 19-20). Less well-established groups in particular can gain quick recognition by incorporating under the new law, and Japanese are also more likely to acknowledge the many groups that do not seek legal status (Yamaoka, 1999: 31).

\section{What of the Future?}

There is no question that many bureaucrats and conservative politicians are learning to talk the talk. Although the idea first arose in deliberations among international NGOs in the early 1990s, the proposal to proclaim 2001 the International Year of Volunteers (IYV) emerged at a UN policy forum held in Japan in 1996, it was the Japanese government's proposal that was put on the UN agenda in 1997, and Japan was the first country to establish an IYV national committee in 1999 (see the IYV website at www.iyv.org). The G-8 Summit that Japan hosted in 2000 was the first to include NGOs formally, and the government even appointed a special 'Ambassador in Charge of Civil Society' (shibiru sosaeti tantō taishi) for the occasion (Kim Reimann, personal communication). Even an exception proves the rule: when an influential LDP politician pressured the Ministry of Foreign Affairs in January 2002 to bar two Japanese NGOs from an international conference held in Tokyo on the grounds that their leader had publicly criticized the government, a great hue and 
cry followed. The prime minister reversed the decision, and the politician came under scathing attacks. National actors aside, assertive local governments collaborated with civil society organizations in the 1990s to challenge the central government even on the kinds of national security issues (e.g., US military bases, nuclear ship visits) over which the state is most eager to assert its prerogatives (Kamimura 2001).

Nevertheless, are state actors sincerely interested in encouraging civic engagement and civil society organizations as positive ends in themselves, or solely as inexpensive means for delegating governmental responsibilities and quieting their critics? Time will tell, but Patricia Maclachlan (2000: 10, 27-28) reminds us that the NPO Law was only one of several pieces of legislation passed in the 1990s that have the potential to rework relations between state and civil society in Japan. Other examples of laws initiated by and for average citizens include the Administrative Procedures Law (1993), the Products Liability Law (1994), and the revised Code of Civil Procedure (1996). The Information Disclosure Law (1999) is especially noteworthy for enhancing government transparency and accountability. Although it made no mention of citizens' right to know, it did entrench their rights to request information from the national government and to seek redress through the judicial system when information is refused.

Even if the Japanese state is (hesitantly and grudgingly) opening up space for civil society, will non-state actors step in to fill this opening? Regarding the so-called 'volunteer revolution', for example, the evidence is ambiguous. On the one hand, Japan ranked lowest among all the developed countries included in a 1996 study of the subject (Atoda, Amenomori, and Ohta, 1998: 108; cf. Yamauchi et al., 1999: 248), and there was unquestionably an element of faddish romanticization to volunteerism that faded with Kōbe's return to normalcy. Moreover, in the provision of social services, at least, the state is 'highly involved' in Japanese voluntarism, Mary Alice Pickert (1999) cautions us: 'The central government defines the boundaries of volunteer activities, the scope of their involvement, and the nature of their work environment through regulations and guidelines ... A volunteer in Japan is someone who is unpaid, not necessarily someone who is independent from the state'. On the other hand, the number of volunteers more than tripled between 1980 and 1997 (rising from 1.6 to 5.5 million), two 1997 surveys revealed that 21.5 percent of all adults and 40.7 percent of college students had engaged in volunteer activities, and 270,000 people offered their help when thousands of tons of crude oil leaked from a Russian tanker off the Japanese coast that year (Yamauchi, 1999: 123; Sōrifu, 1998: 608, 567; Yoshida, 1999: 42).

The evidence for Japanese participation in international NGOs (INGOs) is similarly ambiguous, John Boli (1999: 100-103) found. When countries are ranked by the total number of INGOs to which their citizens belonged in 1997, Japan comes in at 17 th despite its large population and high level of economic development (the United States comes in at 13th). Japan not only ranks behind leaders France, Germany, and Britain, which might not be surprising given the depth of European 
regionalism, but also behind all the small West European democracies, including Norway, whose population is less than one-fortieth Japan's. Japan's ranking by this measure has been stable since 1960, however, so Japanese engagement in INGOs has risen as fast as elsewhere, which is to say extremely rapidly. Although Japan ranks 18th, below all the other advanced industrial democracies, in the number of INGO headquarters, it ranks 9th in the number of regional offices. Finally, 'we should bear in mind that Japan is clearly the most prominent Asian country in all types of INGO involvement . . . and by good measure' (Boli, 1999: 103).

The long-term trends are unquestionably positive. Since the early 1970s, Japan has undergone continuous structural transformation. Increasing affluence and diversity have enhanced the ability of private groups to organize independent of the state and make demands upon it, resulting in a qualitatively different type of political interaction. Japanese politics now has a 'more competitive, strenuously negotiated character' (Allinson, 1993: 48). As the grip of the nation-state and a system of production based on massive mobilizations of capital and labor weakens, Japan seems poised to move in the direction of the decentralization that characterized its history until the late nineteenth century, a decentralization that would reinforce civil society (Inoguchi, 2000: 103, 105). Japanese society as a whole is moving from a security-based society in which individuals pursue cautious, commitment-forming strategies to a trust-based society in which individuals pursue more open, opportunity-seeking strategies (Yamagishi, forthcoming).

Victoria Bestor (1999: 7-8) offers the most sanguine interpretation of the current situation. 'What is happening is a reimagination of civil society ... Through the popular media and other means civil society is being reimagined into an indigenous Japanese concept to bring about changes that are barely being considered by increasingly marginalized bureaucrats, elected leaders, and corporate elites. This reimagination is carving out newly legitimate roles for a true civil sector in Japan.' The degree to which this 'reimagination of civil society' is realized will determine the face of 21st-century Japan.

\section{References}

Allinson, Gary D. (1993), 'Introduction' and 'Analyzing Political Change: Topics, Findings, and Implications', in Gary D. Allinson and Yasunori Sone (eds.), Political Dynamics in Contemporary Japan (Ithaca: Cornell University Press).

Amemiya, Takako (1998), 'The Nonprofit Sector: Legal Background', in Tadashi Yamamoto (ed.), The Nonprofit Sector in Japan (Manchester: Manchester University Press).

Amenomori, Takayoshi and Tadashi Yamamoto (1998), 'Introduction', in Tadashi Yamamoto (ed.), The Nonprofit Sector in Japan (Manchester: Manchester University Press).

Atoda, Naosumi, Takayoshi Amenomori, and Mio Ohta (1998), 'The Scale of the Japanese Nonprofit Sector', in Tadashi Yamamoto (ed.), The Nonprofit Sector in Japan (Manchester: Manchester University Press).

Barshay, Andrew (forthcoming), 'Capitalism and Civil Society in Postwar Japan: Perspectives from Intellectual History', in Frank Schwartz and Susan Pharr (eds.), The State of Civil Society in Japan (New York: Cambridge University Press). 
Bellin, Eva (1995), 'Civil Society in Formation: Tunisia', in Richard Augustus Norton (ed.), Civil Society in the Middle East (Leiden: E. J. Brill).

Bestor, Victoria Lyon (1999), 'Reimagining “Civil Society” in Japan', in Washington-Japan Journal (special issue, spring): 1-10.

Boli, John (1999), 'Global Civil Society and USA/Japan Involvement', in Civil Society: New Agenda for US-Japan Intellectual Exchange (Tokyo: The Japan Foundation Center for Global Partnership).

Bratton, Michael (1989), 'Beyond the State: Civil Society and Associational Life in Africa', World Politics 41(3).

Broadbent, Jeffrey (1998), Environmental Politics in Japan: Networks of Power and Protest (Cambridge: Cambridge University Press).

Bullock, Robert (forthcoming), 'Redefining the Conservative Coalition: Agriculture and Small Business in Japan', in Frank Schwartz and Susan Pharr (eds.), The State of Civil Society in Japan (New York: Cambridge University Press).

Deguchi, Masayuki (1999), 'A Comparative View of Civil Society', Washington-Japan Journal (special issue, spring): 11-20.

Deguchi, Masayuki (2000), 'Not For Profit: A Brief History of Japanese Nonprofit Organizations', Look Japan 45(526): 18-20.

Economic Planning Agency, Social Policy Bureau (1997), Shimin katsudō repōto: Shimin katsudō dantai kihon chōsa hōkokusho [Report on Citizen Activities: Report on a Basic Survey of Citizen Activity Organizations], Tokyo: Ministry of Finance.

Ehrenberg, John (1999), Civil Society: The Critical History of an Idea (New York: New York University Press).

Estévez-Abe, Margarita (forthcoming), 'State-Society Partnerships in the Japanese Welfare State', in Frank Schwartz and Susan Pharr (eds.), The State of Civil Society in Japan (New York: Cambridge University Press).

Freeman, Laurie (forthcoming), 'Media and the Internet in the Development of Civil Society in Japan', in Frank Schwartz and Susan Pharr (eds.), The State of Civil Society in Japan (New York: Cambridge University Press).

Garon, Sheldon (1997), Molding Japanese Minds: The State in Everyday Life (Princeton: Princeton University Press).

Garon, Sheldon (forthcoming), 'From Meiji to Heisei: The State and Civil Society in Japan', in Frank Schwartz and Susan Pharr (eds.), The State of Civil Society in Japan (New York: Cambridge University Press).

Habermas, Jürgen (1989), The Structural Transformation of the Public Sphere: An Inquiry into a Category of Bourgeois Society (Cambridge, MA: MIT Press).

Hann, Chris (1996), 'Introduction: Political Society and Civil Anthropology', in Chris Hann and Elizabeth Dunn (eds.), Civil Society: Challenging Western Models (New York: Routledge).

Hardacre, Helen (1991), 'Japan: The Public Sphere in a Non-Western Setting', in Robert Wuthnow (ed.), Between States and Markets: The Voluntary Sphere in Comparative Perspective (Princeton: Princeton University Press).

Hardacre, Helen (forthcoming), 'After Aum: Religion and Civil Society in Japan', in Frank Schwartz and Susan Pharr (eds.), The State of Civil Society in Japan (New York: Cambridge University Press).

Imata, Katsuji (1999), 'Civil Society in the US and Japan: Polar Opposites', Washington-Japan Journal (special issue, spring): $21-28$.

Imata, Katsuji (2001), 'Players That Make Up the Nonprofit Sector', presented at a June 12 workshop of the Japan Foundation Center for Global Partnership, Tokyo.

Inoguchi, Takashi (2000), 'Social Capital in Japan', Japanese Journal of Political Science 1(1): 73-112.

Iokibe, Makoto (1999), 'Japan's Civil Society: An Historical Overview', in Tadashi Yamamoto (ed.), Deciding the Public Good: Governance and Civil Society in Japan (Tokyo: Japan Center for International Exchange).

Johnson, David (forthcoming), 'A Tale of Two Legal Systems: Prosecuting Corruption in Japan and Italy', in Frank Schwartz and Susan Pharr (eds.), The State of Civil Society in Japan (New York: Cambridge University Press). 
Kamimura, Naoki (2001), 'Japanese Civil Society, Local Government, and US-Japan Security Relations in the 1990s: A Preliminary Survey', in Chieko Kitagawa Otsuru and Edward Rhodes (eds.), Nationalism and Citizenship III (Japan Center for Area Studies (JCAS) Occasional Paper No. 11).

Keane, John (1988), 'Introduction' and 'Despotism and Democracy: The Origins and Development of the Distinction Between Civil Society and the State, 1750-1850', in John Keane (ed.), Civil Society and the State: New European Perspectives (London: Verso).

Keane, John (1998), Civil Society: Old Images, New Visions (Stanford: Stanford University Press).

Maclachlan, Patricia L. (200o), 'Information Disclosure and the Center-Local Relationship in Japan', in Sheila A. Smith (ed.), Local Voices, National Issues: The Impact of Local Initiative in Japanese Policy-Making (Ann Arbor: University of Michigan Press).

Maclachlan, Patricia (forthcoming), 'The Struggle for an Independent Consumer Society: Consumer Activism and the State's Response in Postwar Japan', in Frank Schwartz and Susan Pharr (eds.), The State of Civil Society in Japan (New York: Cambridge University Press).

Maruyama, Masao (1963), Thought and Behaviour in Modern Japanese Politics (London: Oxford University Press).

Matsumoto, Sannosuke (1978), "The Roots of Political Disillusionment: "Public" and"Private" in Japan', in J. Victor Koschmann (ed.), Authority and the Individual in Japan: Citizen Protest in Historical Perspective (Tokyo: University of Tokyo Press).

Menju, Toshihiro and Takako Aoki (1995), 'The Evolution of Japanese NGOs in the Asia Pacific Context', in Tadashi Yamamoto (ed.), Emerging Civil Society in the Asia Pacific Community: Nongovernmental Underpinnings of the Emerging Asia Pacific Regional Community (Singapore and Tokyo: The Institute of Southeast Asian Studies and The Japan Center for International Exchange).

Muramatsu, Michio, Itō Mitsutoshi, and Tsujinaka Yutaka (1986), Sengo Nihon no atsuryoku dantai [Pressure Groups in Postwar Japan], Tokyo: Tōyō Keizai Shinposha).

Norton, Augustus Richard (1995), 'Introduction', in Richard Augustus Norton (ed.), Civil Society in the Middle East (Leiden: E. J. Brill).

Pekkanen, Robert (2000), 'Japan's New Politics: The Case of the NPO Law', Journal of Japanese Studies 26(1): 111-48.

Pekkanen, Robert (forthcoming), 'Molding Japanese Civil Society: State Structured Incentives and the Patterning of Civil Society', in Frank Schwartz and Susan Pharr (eds.), The State of Civil Society in Japan (New York: Cambridge University Press).

Pérez-Díaz, Víctor M. (1995), 'The Possibility of Civil Society: Traditions, Character and Challenges', in John Hall (ed.), Civil Society: Theory, History, Comparison (Cambridge: Polity Press).

Pharr, Susan J., and Robert D. Putnam (eds.) (2000), Disaffected Democracies: What's Troubling the Trilateral Countries? (Princeton: Princeton University Press).

Pharr, Susan (forthcoming), 'Targeting by an Activist State: Japan as a Civil Society Model', in Frank Schwartz and Susan Pharr (eds.), The State of Civil Society in Japan (New York: Cambridge University Press).

Pickert, Mary Alice (1999), 'Endangered Service: The Decline of Volunteer Firefighters in Japan', presented at the Eleventh Ph.D. Kenkyūkai Conference of the International House of Japan, Tokyo.

Robert D. Putnam (1993), Making Democracy Work: Civic Traditions in Modern Italy (Princeton: Princeton University Press).

Reimann, Kim (forthcoming), 'Building Global Civil Society from the Outside In? Japan's Development NGOs, the State, and International Norms', in Frank Schwartz and Susan Pharr (eds.), The State of Civil Society in Japan (New York: Cambridge University Press).

Salamon, Lester M., Helmut K. Anheier, Regina List, Stefan Toepler, S. Wojciech Sokolowski, and Associates (eds.) (1999), Global Civil Society: Dimensions of the Nonprofit Sector (Baltimore: The Johns Hopkins Comparative Nonprofit Sector Project).

Schwartz, Frank (forthcoming), 'What Is Civil Society?', in Frank Schwartz and Susan Pharr (eds.), The State of Civil Society in Japan (New York: Cambridge University Press). 
Sōrifu [Prime Minister's Office] (1998), Yoron chōsa nenkan [Public Opinion Survey Yearbook], Tokyo: Naikaku sōri daijin kanbō kōhokushitsu.

Suzuki, Akira (forthcoming), 'The Death of Unions' Associational Life? Political and Cultural Aspects of Enterprise Unions', in Frank Schwartz and Susan Pharr (eds.), The State of Civil Society in Japan (New York: Cambridge University Press).

Tsujinaka, Yutaka (1996), 'Interest Group Structure and Regime Change in Japan', in I. M. Destler and Hideo Satō (eds.), Maryland/Tsukuba Papers on US-Japan Relations (College Park, MD: University of Maryland).

Tsujinaka, Yutaka (forthcoming), 'Japan's Civil Society Organizations in Comparative Perspective', in Frank Schwartz and Susan Pharr (eds.), The State of Civil Society in Japan (New York: Cambridge University Press).

Verba, Sidney, Norman H. Nie, and Jae-On Kim (1978), Participation and Political Equality: A SevenNation Comparison (Cambridge: Cambridge University Press).

Wada, Jun (1999), 'Civil Society in Japan Through Print and Statistical Data', in Tadashi Yamamoto (ed.), Deciding the Public Good: Governance and Civil Society in Japan (Tokyo: Japan Center for International Exchange).

Weber, Max (1949), "'Objectivity" in Social Science and Social Policy', in Edward A. Shils and Henry A. Finch (eds.), The Methodology of the Social Sciences (New York: The Free Press).

Weber, Max (1952), The Protestant Ethic and the Spirit of Capitalism (New York: Charles Scribner's Sons).

White, Gordon (1994), 'Civil Society, Democratization and Development (I): Clearing the Analytical Ground', Democratization $1(3)$.

Wolferen, Karel van (2 December 1991), 'An Economic Pearl Harbor?' New York Times, sec. A.

Yamagishi, Toshio (forthcoming), 'Trust and Social Intelligence in Japan', in Frank Schwartz and Susan Pharr (eds.), The State of Civil Society in Japan (New York: Cambridge University Press).

Yamamoto, Tadashi (1998), 'The State and the Nonprofit Sector in Japan' and 'Current Issues and Future Agenda', in Tadashi Yamamoto (ed.), The Nonprofit Sector in Japan (Manchester: Manchester University Press).

Yamamoto, Tadashi (1999), 'Emergence of Japan's Civil Society and Its Future Challenges', in Tadashi Yamamoto (ed.), Deciding the Public Good: Governance and Civil Society in Japan (Tokyo: Japan Center for International Exchange).

Yamaoka, Yoshinori (1999), 'Recent Trends in the Nonprofit Sector in Japan, Including Background on the New NPO Law', in Ruri Kawashima and Betty Borden (eds.), Civil Society: Japanese Experiment and American Experience (New York: Japan Society).

Yamauchi, Naoto (1999), NPO Detabukku [NPO Data Book], Tokyo: Yuhikaku.

Yamauchi, Naoto, Hiroko Shimizu, S. Wojciech Sokolowski, and Lester M. Salamon (1999), 'Japan', in Lester M. Salamon, Helmut K. Anheier, Regina List, Stefan Toepler, S. Wojciech Sokolowski, and Associates (eds.), Global Civil Society: Dimensions of the Nonprofit Sector (Baltimore: The Johns Hopkins Comparative Nonprofit Sector Project).

Yoshida, Shinichi (1999), 'Rethinking the Public Interest in Japan: Civil Society in the Making', in Tadashi Yamamoto (ed.), Deciding the Public Good: Governance and Civil Society in Japan (Tokyo: Japan Center for International Exchange). 